The BDJ News section accepts items that include general news, latest research and diary events that interest our readers. Press releases or articles may be edited, and should include a colour photograph if possible. Please direct your correspondence to the News Editor, Arveen Bajaj at the BDJ, 64 Wimpole Street WIG 8YS or by email to bdj@bda.org

\section{Booklet wins prize}

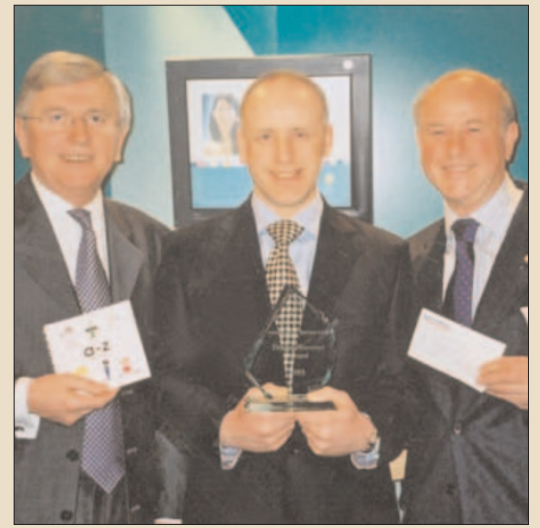

David A. Houston of Western-SuperMare won a $£ 500$ prize for his selfdrawn cartoon booklet about dental health. He was presented with a Cordent-Brian Lux Dental Humour Award 2003 at the Denplan stand at the recent BDTA dental exhibition in Birmingham. (From left to right: David Phillips, David A Houston and Brian Lux).

\section{New BDTA President}

The British Dental Trade Association has welcomed Peter Gowers as its new President. The appointment was officially announced at the BDTA's recent midwinter meeting, held at the Royal Institute of British Architects.

Managing director of Panadent Ltd, Mr Gowers has served on the council and finance and executive committees for several years and has chaired a number of key BDTA committee meetings over the past ten years.

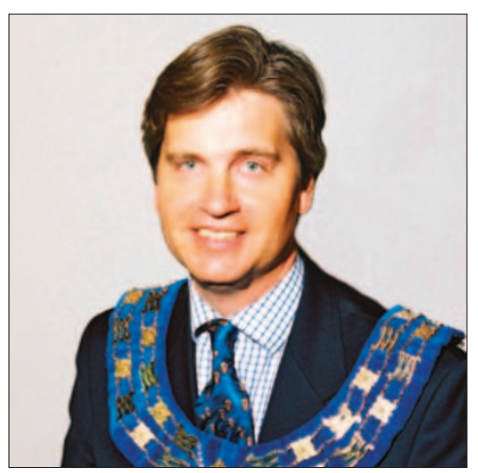

\section{Tooth fairies raise charity cash}

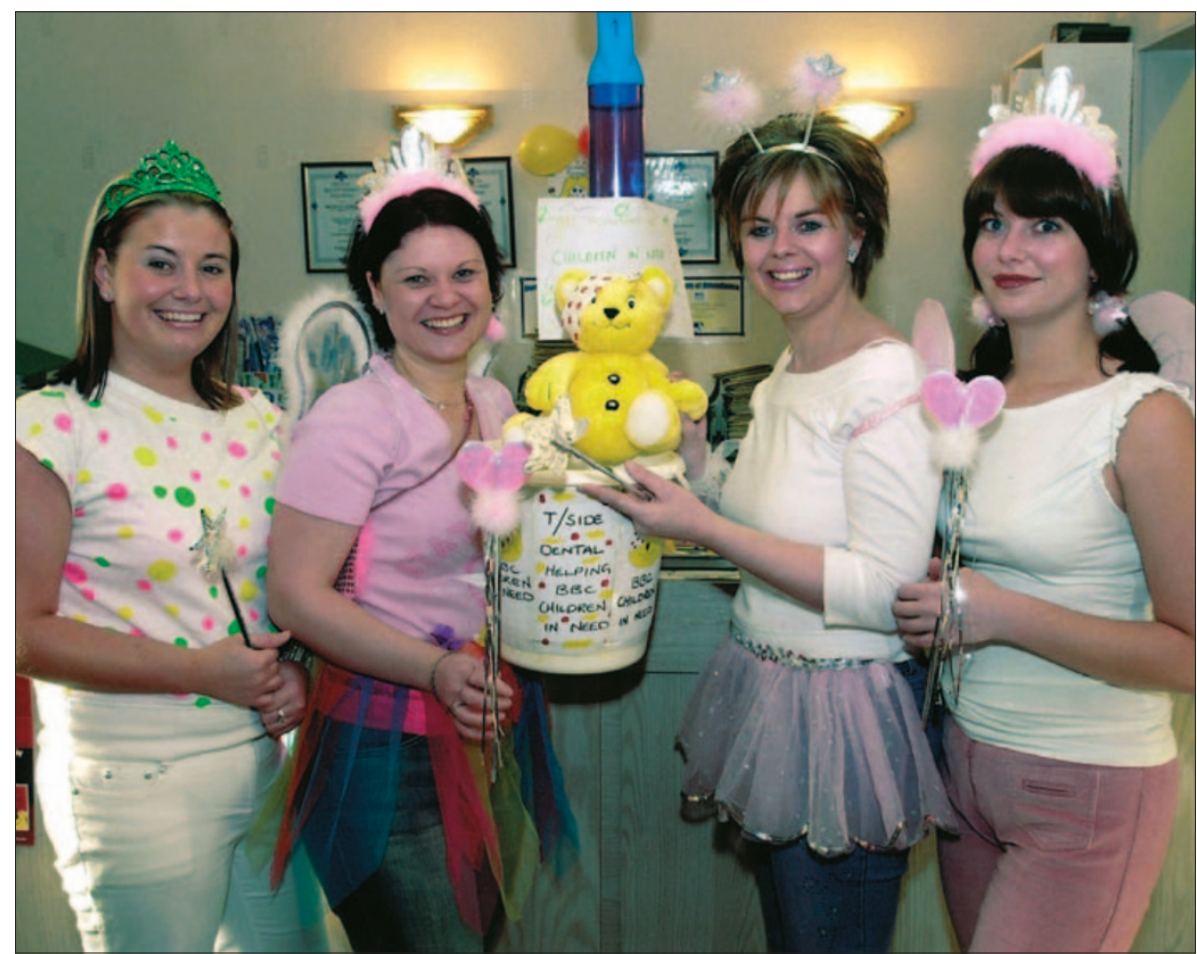

Integrated Dental Holdings Tannochside Dental Centre raised just over $€ 145$ for Children in Need by dressing up as tooth fairies, complete with wings and wands and organising competitions for the younger patients. The team also enlisted the support of the local Safeways store, who donated apples and oranges for patients. (Pictured left to right: Stacey Allen, Carol Dyer, Becky Brown and Michelle McParland).

\section{GDC produces new patient leaflet}

The GDC have produced a new leaflet for patients who have a complaint about their dental treatment.

The publication, What to do if you have a problem with a dental professional, explains who can help if patients have a complaint about their dental treatment and describes the type of complaints that the GDC can help with.

It also outlines how to

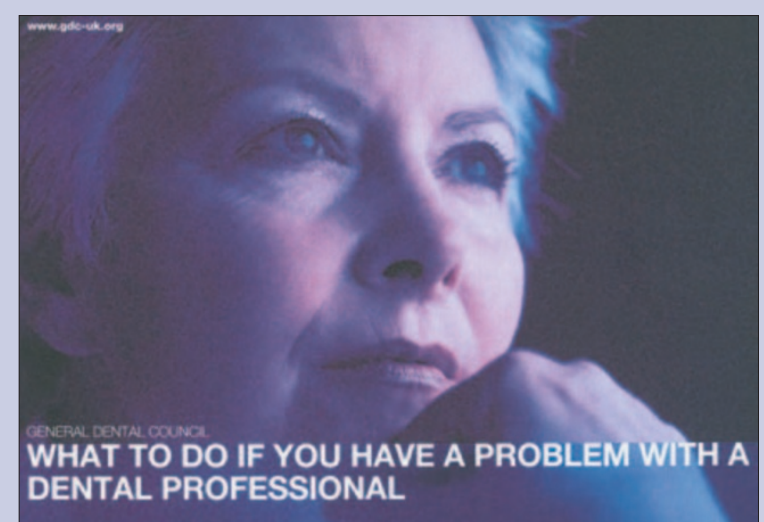

make a complaint to the GDC and what the procedure is after the complaint had been made.

Copies have now been sent to a range of organisations, including consumer and patient groups, primary care trusts and citizens' advice bureaux in the UK and are available on the website www.gdc-uk.org. 


\section{DIARY}

March 2004

Neuro-disability and Dentistry - The Patients and the Practical

Date: 09.03.04

Venue: Royal Hospital for Neurodisability, London

Contact: Conference Administrator

Tel: +44 (0) 02087804500 ext 5236

Email:conferences@rhn.org.uk

\section{April 2004}

Avoiding failures and maximising success in restorative dentistry

Date: 02.04 .04

Venue: The Salmons Centre

Contact: Elisabeth Jarrett

Tel: +44 (0)1892 654384

Email: elisabeth.jarrett@btinternet.com

Medicare India 2004

Date: 06-08.04.04

Venue: Pragati Maidan, New Delhi

Contact: Rob Grant

Tel: +44 (0) 2077238020

Fax: +44 (0) 2077238060

Email: rob.grant@kinexlog.com

www.medicare-expo.com

\section{May 2004}

British Dental Conference and Exhibition

Date: 06-08.05.04

Contact: Delegate Management Services

Venue: Bournemouth International

Centre (BIC)

Tel: 08701666625 or + 44 (0) 1252

771425 (from overseas)

Fax: 08705228890 or + 44 (0) 1252

771790 (from overseas)

www.bda-events.org

\section{Science and pain exhibition}

Over 170 objects and artworks - many rare and unseen - from the original collections of Sir Henry Wellcome are to form the basis of a new exhibition on pain. A collaboration between The Wellcome Trust and the Science Museum, the exhibition Pain: Passion, Compassion, Sensibility explores the changing cultural place of pain and the role of science in shaping our beliefs.

It looks at visual and verbal representations, medical attempts to deal with pain, examinations of modern and contemporary theories about the nature of pain and a look into our reactions to the pain of others.

As well as a carved wooden decapitated head, a 17th century German execution mask, torture equipment and a 16th century thumb screw it includes the tooth of an Egyptian ghoul said to cure neck pain and 18th century German dental forceps.

Curated by the leading Spanish philosopher, Javier Moscoso, the exhibition looks at medicine through a mixture of science, art and history and the curator uses his native Spain as

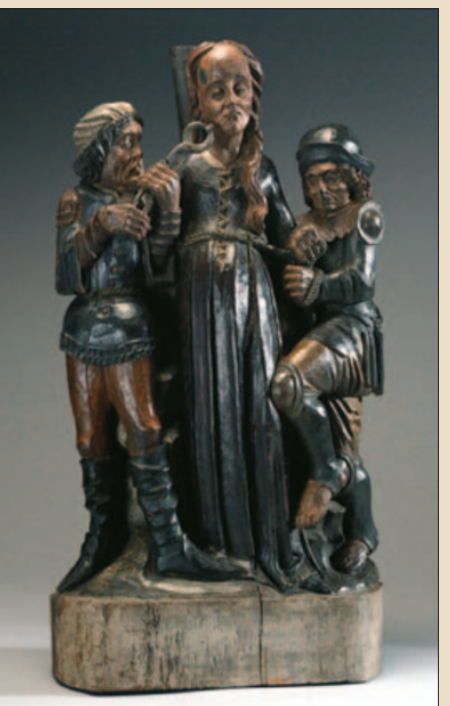

Wooden figure of St Appollonia, patron saint of toothache sufferers and two torturers, France 19th century. (Image courtesy of the Science Museum) a cultural reference point. Pain: Passion, Compassion, Sensibility runs from 13 February to 20 June 2004 at the Science Museum, London.

\section{Kick boxing dentist wins medal}

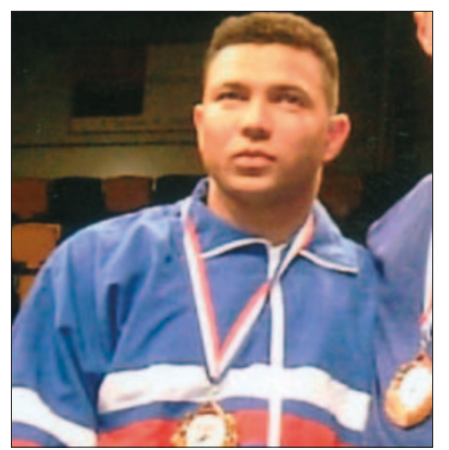

Karifala Tarawali recently won the bronze medal in the World Full Contact Kick Boxing Championships held in Paris.

A vocational dental practitioner from the North Western Deanery's vocational training scheme at the University of Manchester, Dr Tarawali from Sierra Leone qualified in Volgograd in 2000.

He has successively held the posts of Dental Observer, Dental Attachment and SHO. He is also a member of the Englshi Ju-jitsu team and will be going to the World Championships in Canada in June 2004. 


\section{Police appeal to dentists to help identify murder victim}

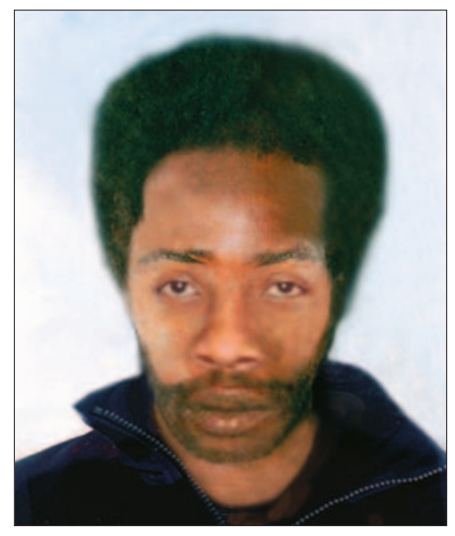

A computer generated image of the victim
Police are appealing to dentists for help with the identification of a murder victim. At $1530 \mathrm{hrs}$ on Friday 16th January 2004, an unknown male was found at the foot of Beachy Head Cliffs, Sussex and the matter is being treated as murder.

The police are requesting dentists to see if they recognise the physical appearance or the description of his dentition. He was a black (African Carribean) male aged approximately 30 years (between 25-35 years ), 5 foot 9 inches in height with a slim, athletic build. There were no visible marks, scars or tattoos and he had an afro hair style 5-6 inches long, cut slightly shorter above ears, with a high hair line.

He had a full beard and moustache. An incident room is being run from Sussex House in Brighton under the name of Operation Dundee. The senior investigation officer for this operation is DCI 0'Donnell. The incident room can be contacted on 08456070999.

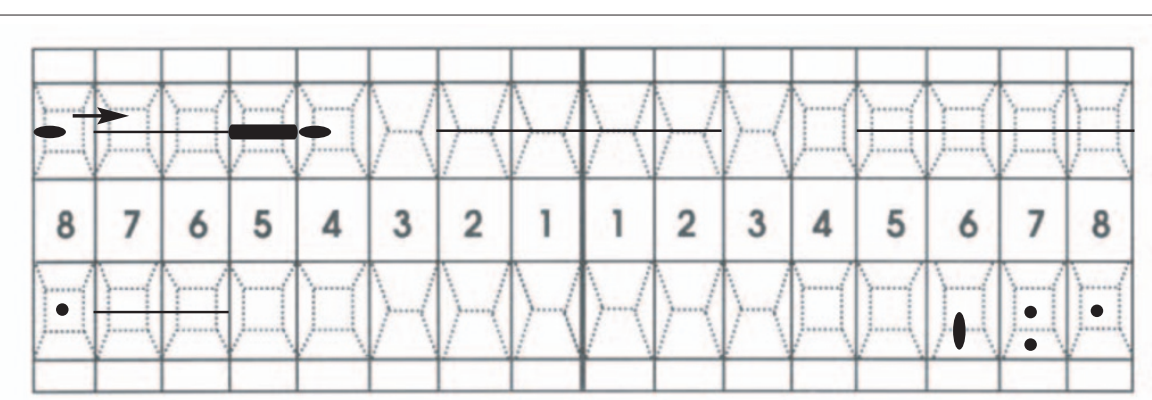

(LR8 tilted forward)
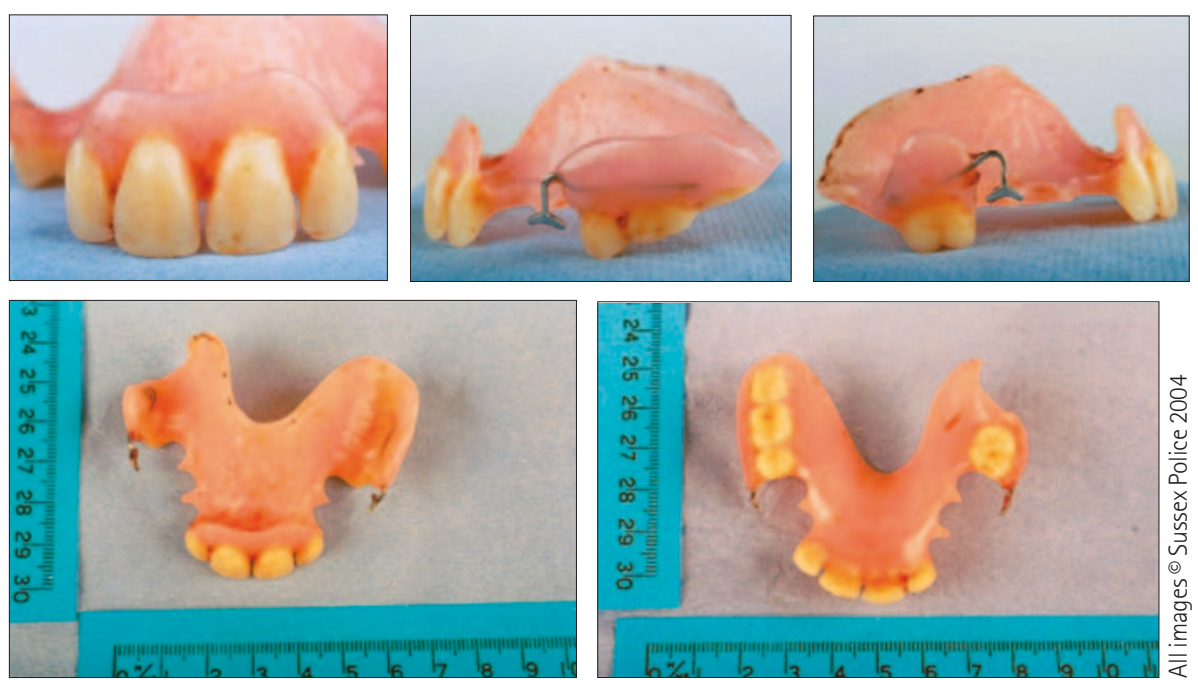

\section{Verdict reached on GDC case}

On 21 January the General Dental Council (GDC) prosecuted Mr Alexander Gibson for the illegal practise of dentistry.

The case was heard at Blackpool Magistrates' Court. At the hearing, Mr Gibson pleaded guilty to treating patients after his name had been erased from the Dentists Register.

As Mr Gibson was erased from the Dentists Register in 2003 having been found guilty of serious professional misconduct, he was fined $£ 9,000$ and ordered to pay a contribution to the Council's costs as well as pay $£ 400$ compensation to a patient.

Antony Townsend, GDC Chief Executive and Registrar said that the fines imposed on Mr Gibson reflected the seriousness with which the magistrates viewed his actions. 